\title{
Electrospun natural rubber fibers-based flexible conductive membranes
}

Guilherme Dognani ${ }^{1}$, André Antunes da Silva ${ }^{1}$, Flávio Camargo Cabrera ${ }^{1}$, Fabrício Luiz Faita ${ }^{2}$,Carlos Alberto Tello Saénz ${ }^{1}$, Ivan Helmulth Bechtold ${ }^{3}$, Aldo Eloízo Job ${ }^{1}$, Deuber Lincon da Silva Agostini ${ }^{1}$

\footnotetext{
${ }^{1}$ Departamento de Física, Faculdade de Ciências e Tecnologia, Universidade Estadual Paulista "Júlio de Mesquita Filho" (FCT/UNESP), CEP: 19060-080, Presidente Prudente, SP, Brazil.

${ }^{2}$ Instituto de Física, Universidade Federal do Rio Grande do Sul (UFRGS), CEP: 91511-970, Porto Alegre, RS, Brazil.

${ }^{3}$ Departamento de Física, Universidade Federal de Santa Catarina (UFSC), CEP: 88040-900, Florianópolis, SC, Brazil. e-mail: dognani.g@gmail.com, andre_as007@hotmail.com, flavioccabrera@gmail.com, tello.saenz@unesp.br, aldo.job@ unesp.br,deuber.agostini@unesp.br, fabricio.faita@ufrgs.br, ivan.bechtold@ufsc.br
}

\section{ABSTRACT}

In recent years, the technique of electrospinning has been used to develop a novel class of micro- and nanoscale materials based on fibrous structures. Several polymers, in particular elastomers, that have been implemented in this process rely on properties such as elasticity, flexibility, biocompatibility, and low cost. Herein, we describe for the first time the electrospinning of natural rubber fibers without polymeric matrix to obtain self-standing non-woven mats and oriented elastomeric fibers. The fibers average diameters were approximately $5.5 \mu \mathrm{m}$. Polyaniline (PAni) was deposited on the membrane surface in order to enhance the conductive properties making easy the charge transportation. We have obtained biocompatible and flexible fibrous materials using natural rubber, this research opens up possibilities of using micro and nanofibers of only-natural rubber in many applications including sensors preparation.

Keywords:Electrospinning; Fiber technology; Microstructure; Polymer; Sensors.

\section{INTRODUCTION}

Electrospinning is a process that uses electric fields to produce nonwoven materials with high porosity, large surface area, small diameters, and uniform fibers; there is great industrial and scientific interest in these materials because of their many potential applications [1-3], as membranes for drug delivery [4], for tissue engineering [5], for water treatment [6], for food packing applications [7], sensors [8,9] and others. A typical electrospinning setup comprises a syringe pump to control the solution flow rate, a syringe with a small-diameter metallic needle, a high-voltage power supply, and a grounded collector plate (Fig. 1) [10,11].

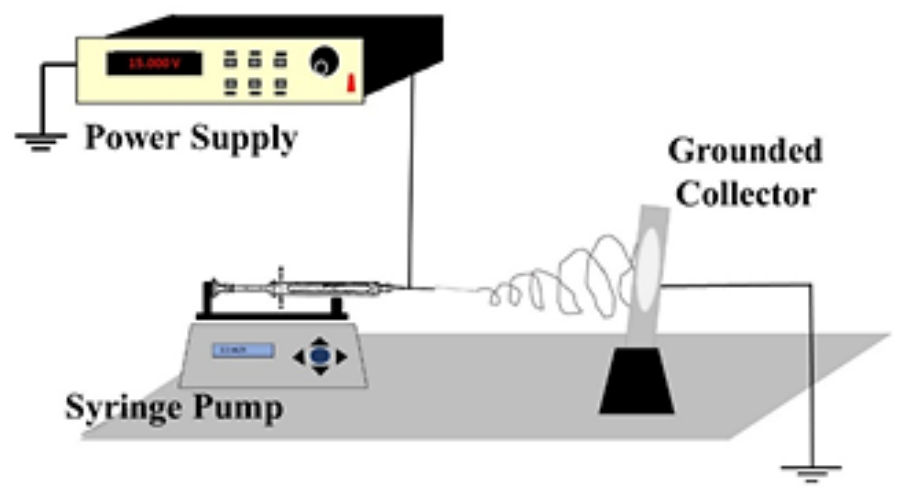

Figure 1: Schematic illustration of the homemade electrospinning setup using a syringe pump with single syringe, a high-voltage power supply and a grounded collector plate.

Researchers are increasingly shifting their attention toward the use of polymeric materials in order to obtain submicron and nanometer fibers by electrospinning [12-13]. Of the polymers that have been utilized, elastomers are attracting 
increasing interest, and their use could be an important strategy in the development of flexible electrospun mats. Silicone rubber [4,17] and synthetic rubbers such as polybutadiene rubber (BR) and polyisobutylene-isoprene rubber (IIR) [11] have been used to produce electrospun fibers containing inorganic fillers such as silver nanoparticles (AgNPs) [11] and a europium $\left(\mathrm{Eu}^{3+}\right)$-like luminescent filler [18], more recently fluorescent polymer/acrylonitrile butadiene rubber (NBR) blends [19] and epoxidized natural rubber [20] have been studied.

Natural rubber (NR) is a unique elastomeric material whose flexibility, biocompatibility, elasticity, and low cost have led to its widespread use [21-24]. In recent studies, NR has been used to produce many materials such as thermo-mechanical actuators [25], nanocomposites to be used as gas barriers [26], shape memory polymers [27], and polymer networks used for environmental gas recognition [28, 29]. By combining the properties of NR with the electrospinning technique, it is possible to obtain highly flexible fibers and nonwoven porous mats with good mechanical resistance and elasticity. However, the production of electrospun fibers using only natural rubber has not yet been explored.

Recently, authors have reported attempting to electrospinning a blend of natural rubber (non-vulcanized) and polycaprolactone (PCL) using a maximal ratio of $50 \%$ of natural rubber in a PCL matrix [30]. Sithornkul et. al. reported electrospinning a blend of vulcanized NR and acrylonitrile-butadiene-styrene to investigate the parameters of electrospinning [31]. Mascia et al. produced binary blend of an epoxidized natural rubber and PLA using compatibilizer ENR-g-JM [32], still using PLA like matrix Cosme et al. developed a blend from PLA/ epoxidized natural rubber but without compatibilizer [33]. A number of challenges must be addressed when electrospinning NR: for example, it is difficult to obtain the ideal process parameters, such as solution flow, voltage, distance between the collector and the injector. Moreover, the amount of water present in the NR latex increases the time required for drying and evaporation of the solvent during the electrospinning process, i.e. when the fibers are deposited over the collector losing their fiber characteristic becoming a film material. Here, we report the development of a new material based on electrospun NR fibers. We have produced organic fibers deposited on a collector or substrate in an oriented arrangement; these fibers show high linearity and submicron size. We have also produced self-standing non-woven mats from Polyaniline-coated natural rubber $\left(\mathrm{NR} / \mathrm{PAni}{ }_{\mathrm{Fibers}}\right)$ as a possible new material to apply in the sensors industry.

\section{MATERIALS AND METHODS}

NR membranes were prepared using latex collected from different rubber trees (Hevea brasiliensis) of the RRIM 600 clone in Indiana City, Sao Paulo State, Brazil (Fig. 2a). After extraction, the latex samples were stabilized with ammonium hydroxide $(2 \% \mathrm{v} / \mathrm{v})$. The stabilized latex was centrifuged at $14000 \mathrm{rpm}(15,340 \mathrm{~g})$ in a Microhemato Bench Centrifuge (Model 2410, Fanem) to separate out the solid rubber phase. After centrifugation, the latex was separated into three phases (Fig. $2 b$ ): the solid rubber phase (cream phase), composed mostly of isoprene monomers and containing approximately $60-40 \%$ dry rubber; the serum phase, composed of approximately 1.0 to $1.8 \%$ protein, 1.0 to $1.2 \%$ carbohydrate, 0.4 to $1.1 \%$ neutral lipids, 0.4 to $0.5 \%$ polar lipids, 0.4 to $0.6 \%$ inorganic lipids, $0.4 \%$ amino acids and amines, various other components, and 50 to $60 \%$ water; and the bottom fraction, which contained a portion of the monomers and metal ions obtained from interactions between the plant and soil [15]. The rubber cream phase was removed and annealed at $50^{\circ} \mathrm{C}$ until completely dry.

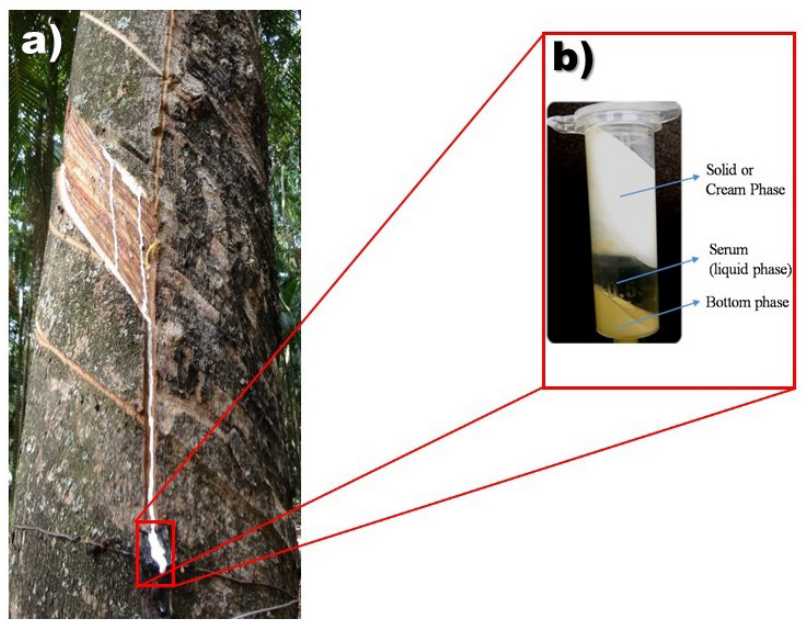

Figure 2: a) Latex extracted from Hevea brasiliensis from different trees was collected. b) Latex separated into three phases (cream phase, serum and, botton phase). 
To prepare the solution for electrospinning, the dried rubber phase was diluted in toluene to a concentration of 20.0 $\mathrm{mg} \mathrm{mL}^{-1}$ under constant stirring for $48 \mathrm{~h}$ to form a rubber solution (NRL). To confer an electrostatic charge to the NRL, was added $30 \mathrm{wt} \%$ of analytical-grade ethanol (Labsynth Products for Laboratories) to the dried rubber/toluene mixture.

The electrospinning system was composed of a high-voltage (15kV) power supply (Spellman Bertan Series 225), a syringe pump (Cole Parmer) with a flow rate of $0.50 \mathrm{~mL} \mathrm{~h}^{-1}$, and a plastic syringe equipped with a 23-gauge metallic needle. To prevent problems with the solution outflow, a 50-W halogen lamp was included in the system, to maintain a temperature of approximately $40{ }^{\circ} \mathrm{C}$ to prevent the solvent from evaporating before the fibers reached the collector, which was placed a distance of $0.1 \mathrm{~m}$ from the needle. An evaluation of the optimal parameters for producing natural rubber fibers $\left(\mathrm{NR}_{\mathrm{Fibers}}\right)$ is presented in the Supporting Information. To analyze the structural and thermal behavior of the electrospun fibers, membranes by casting were produced. The $10 \mathrm{~mL}$ of the solution previously prepared for electrospinning was poured into a glass petri dish $(\phi 90 \mathrm{~mm})$, then was dried in an oven above $65^{\circ} \mathrm{C}$ for $12 \mathrm{~h}$ in order to evaporate the solvent content.

To polymerize the PAni was used the MacDiarmid method $[34,35]$. The aniline was acquired by Labsynth and was previously distilled. The polymerization process was performed using a 5:1 molar ratio of monomer:oxidant. In this sense, the mats were immersed in $0.2684 \mathrm{~mol}$ of the aniline and $300 \mathrm{~mL}$ of $1 \mathrm{M} \mathrm{HCl}$ (hydrochloric acid). In another beaker 0.0505 mol of $\left(\mathrm{NH}_{4}\right)_{2} \mathrm{~S}_{2} \mathrm{O}_{8}$ (Ammonium persulfate) were solubilized in $200 \mathrm{~mL}$ of $1 \mathrm{M} \mathrm{HCl}$, then the oxidant solution was added slowly in the first solution maintaining the temperature at $0{ }^{\circ} \mathrm{C}, 20$ minutes under constant stirring. The mats were withdrawn, washed with $1 \mathrm{M} \mathrm{HCl}$ and dried in desiccator.

Characterization of the electrospun fibers was performed using optical microscopy (OM) to evaluate the morphology of the materials produced. A Carl Zeiss optical microscope with a digital camera (AxioCam MRC5) and a nominal magnification of up to 1500x was used. In addition, a scanning electron microscope (SEM; Carl Zeiss, EVO LS 15) was used to perform a complementary study of the structural properties of the $\mathrm{NR}_{\mathrm{Fibers}}$. FT-IR spectroscopy with mode ATR (model Tensor 27, Bruker) was performed in the range from 600 to $4000 \mathrm{~cm}^{-1}$ with 64 scans and $4 \mathrm{~cm}^{-1}$ spectral resolution in order to evaluate whether electrospinning modified the polymeric structure of $\mathrm{NR}_{\text {Fibers }}$ compared to that of common NR membranes prepared by casting (annealed at $65^{\circ} \mathrm{C}$ in the over during $12 \mathrm{~h}$ ). The thermal behavior was studied by TGA (model 209, Netzsch). After the polyaniline coating, the UV-Vís spectrometer (model 1800, Shimadzu) was carried out to confirm the emeraldine form of the conductive polymer. For evaluate the fibers conductive properties was used the DC with a Keithey Source (Model 617Programmable Electrometer) by the two-point method applied from -0.5 to $0.5 \mathrm{~V}$.

\section{RESULTS AND DISCUSSIONS}

A self-standing non-woven mat of neat natural rubber (porous membrane) microscopy image is shown in Fig. 3a. The image shows the high porosity into the fibrous mat. The preparation of fibrous membranes results in increased surface area and shows great promise for the production of implanted devices, drug delivery systems, and biological filters.
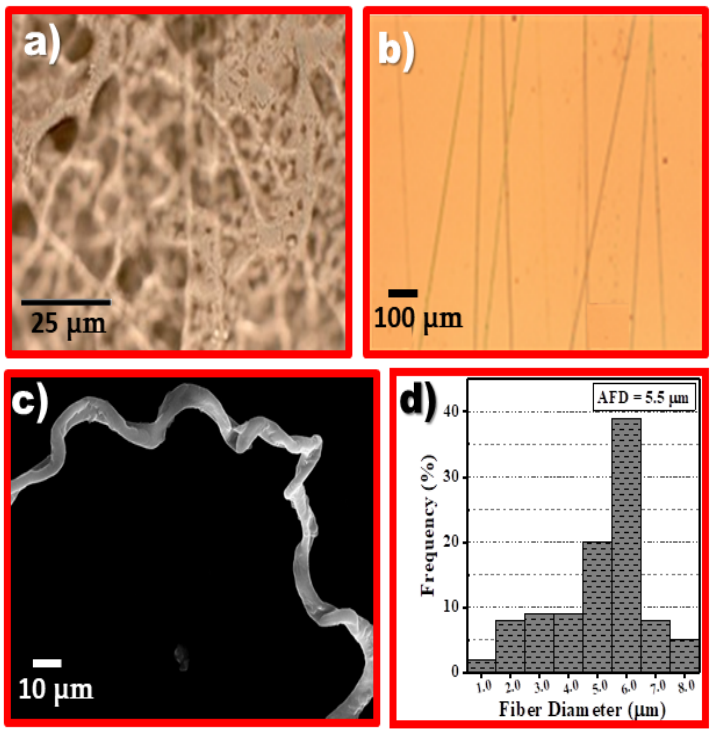

Figure 3: a) Optical micrograph of self-standing non-woven mat of neat natural rubber $\left(\mathrm{NR}_{\mathrm{Fiber}}\right)$ produced with increase 1000x. b) Optical micrograph of oriented fibers produced with increase 400x. c) SEM image of isolated fibers electrospun with magnification of 2000x. d) Histogram of fibers diameter distribution for the $\mathrm{NR}_{\text {Fibers }}$. 
In addition, when a rotary collector was used to control the mats porosity (i.e., to ensure uniformity), oriented fibers were obtained (Fig. 3b). The characteristics of the fibers was observed, mainly the linearity and the fiber thickness, varied under the different electrospinning parameters tested (Supporting Information).

To produce oriented fibers, we used a rotary collector $(30 \mathrm{rpm})$ on which the fibers were deposited onto coupled glass slides (Fig. 4a). To produce self-standing non-woven mats, the fibers were deposited on a stationary stainless-steel plate (Fig. 4b). The SEM micrograph (Fig. 3c) shows the morphology of a single fiber at a magnification of 2000x. A relatively smooth surface is observed, with well-formed fibers. ImageJ ${ }^{\circledR}$ software was used to measure the fiber diameter and revealed that the $\mathrm{NR}_{\text {Fibers }}$ deposited in self-standing mats had an average diameter of $5.5 \mu \mathrm{m}$.
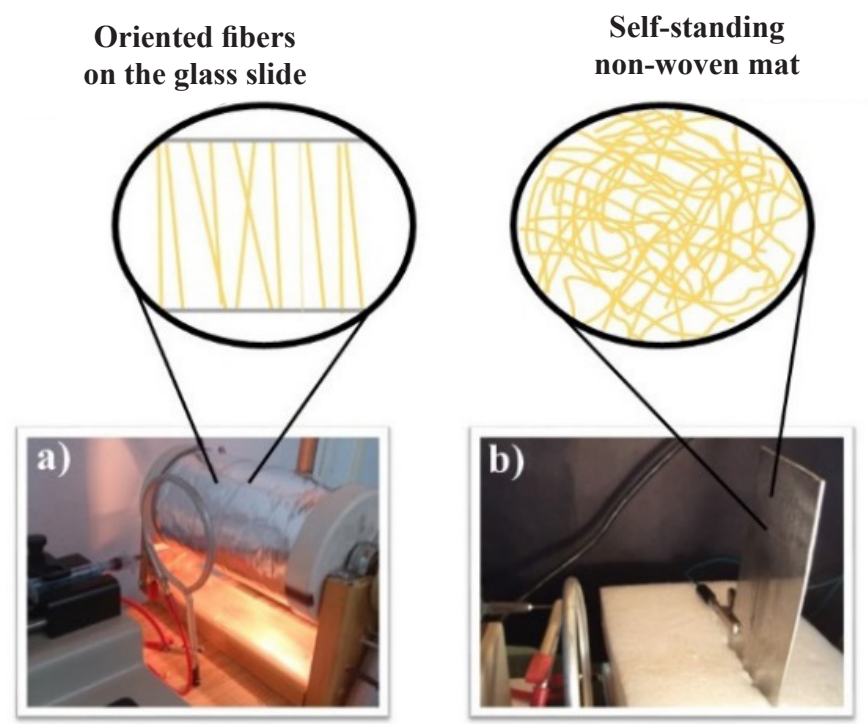

Figure 4: a) Rotary collector for deposit the oriented fibers on glass slides, was used a rotation of $30 \mathrm{rpm}$ in this collector. b) The stainless-steel plate for deposit the self-standing non-woven mats.

Fig. 5 shows FT-IR/ATR spectra for NR (casting membranes) and $\mathrm{NR}_{\text {Fibers }}$ (self-standing mats). The spectra show vibrational bands characteristic of cis 1,4 poly-isoprene. The bands between 3666 and $3105 \mathrm{~cm}^{-1}$ can be attributed to water vapor. The absorption bands at 3007, 2929 and, $2849 \mathrm{~cm}^{-1}$ can be assigned to various functional groups of NR: asymmetric stretching of $\mathrm{C}=\mathrm{C}$ and $\mathrm{CH}$ in the $-\mathrm{CH}_{3}$ region and symmetric stretching of $\mathrm{CH}$ in the $-\mathrm{CH}_{2}$ region, respectively. The band at $1659 \mathrm{~cm}^{-1}$ arises from $\mathrm{C}=\mathrm{O}$ symmetric stretching, the band at $1447 \mathrm{~cm}^{-1}$ from $\mathrm{C}=\mathrm{C}$ stretching, the band at $1375 \mathrm{~cm}^{-1}$ from angular deformation $(\delta)$, and the band at $839 \mathrm{~cm}^{-1}$ arises from angular deformation of the $\mathrm{C}=\mathrm{CH}$ group $[15,36,37]$. There are no observable differences between the $\mathrm{NR}$ and $\mathrm{NR}_{\text {Fibers }}$ spectra, indicating that electrospinning generated no structural modifications and that the elastomeric properties, such as flexibility and elasticity (mechanical resistance), of the natural rubber polymer were maintained.

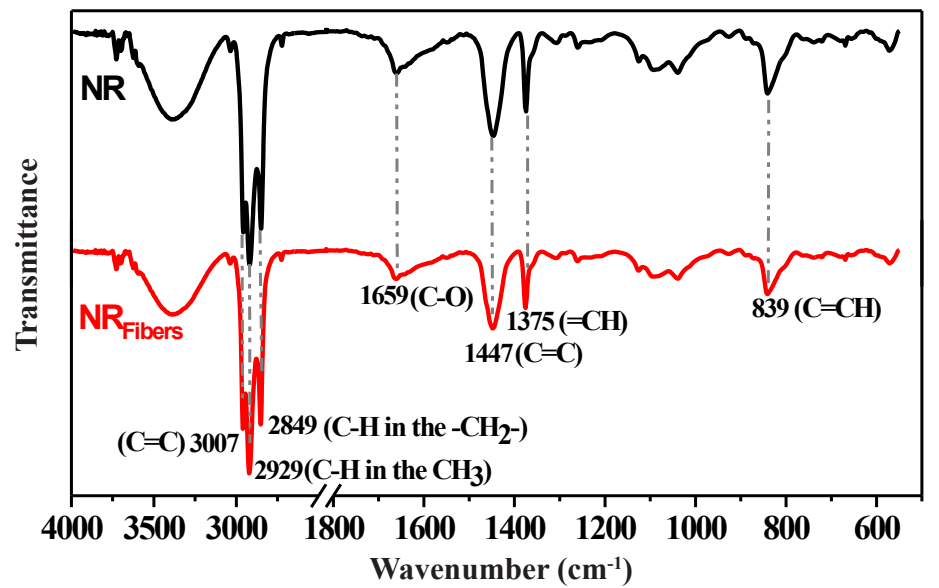

Figure 5: FT-IR spectra of natural rubber) produced by casting method (NR and natural rubber fibers produced by electrospinning $\left(\mathrm{NR}_{\text {Fibers }}\right)$. 
In addition to the similarity of the FTIR spectra for both samples, the thermal similarity was also observed in Fig.6. The profile of the curves were very similar with a displacement of $2{ }^{\circ} \mathrm{C}$ in the main degradation stage of the NR (as seen in the DTG peaks), which is related to polyisoprene degradation [15, 38]. Two peaks ( 432 and $494^{\circ} \mathrm{C}$ ) were observed for the electrospun sample, which may have occurred due the stretching of the rubber chains during the electrospinning process.

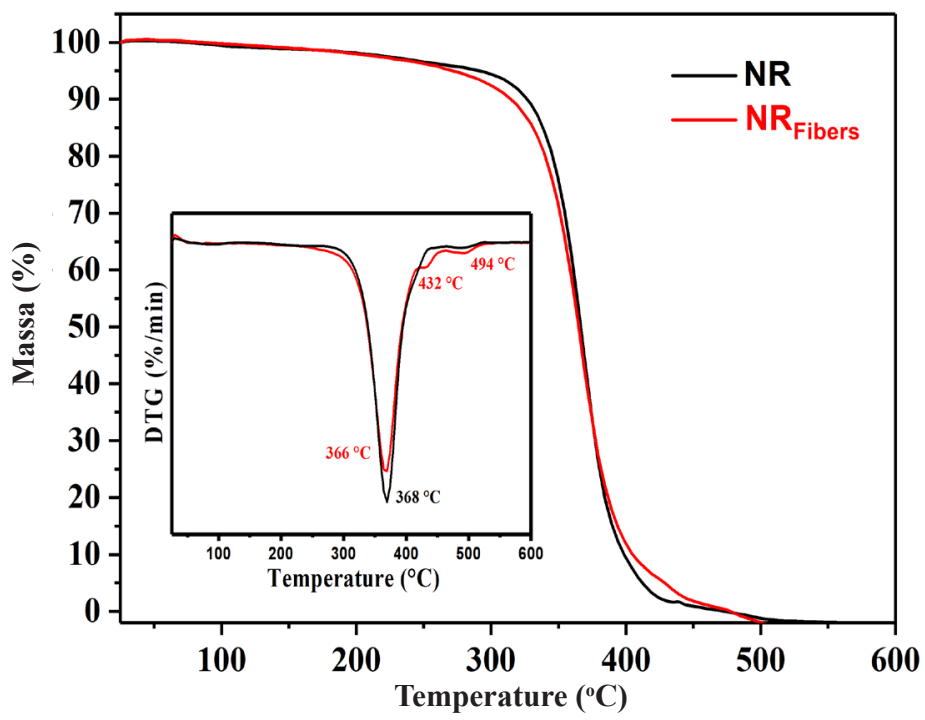

Figure 6:TGA and DTG curves for NR (casting membranes) and $\mathrm{NR}_{\text {Fibers }}$ (electrospun mats).

The produced mats present properties to be applied in different materials, including the sensors can be easily produced with this flexible mat. Then, the electrospun mat was coated with PAni, a polymereasily synthesized, chemically stable at room temperature conditions, high conductivity, and low cost [39]. To verify the presence of polyaniline in the conductive state (emeraldine salt), UV-Vis spectroscopy analysis was performed. Fig. 7 shows the presence of PAni absorption bands at $408 \mathrm{~nm}$ and $799 \mathrm{~nm}$, which refers to the $\pi$ bond transition in the benzenoids unites and the excitonic transitions for the polymer protonation, respectively $[28,30]$.

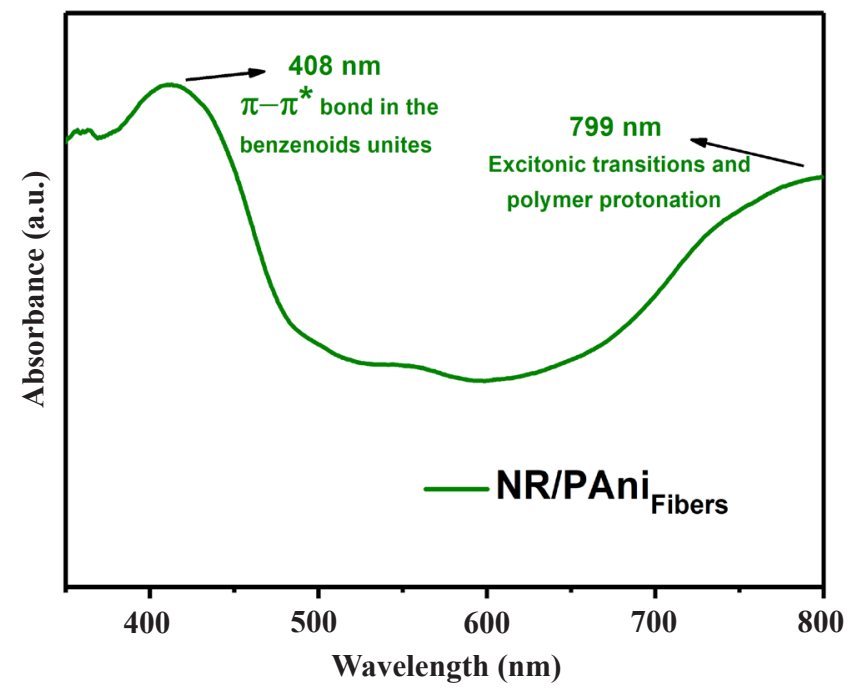

Figure 7: UV-Visible spectrum of the natural rubber/polyaniline fibers $(\mathrm{NR} / \mathrm{PAni}$ Fibers $)$ showing the presence of polyaniline on fibers.

The Figure 8 shows the current-voltage (I-V) characteristics of the $\mathrm{NR}_{\text {fibers }}$ and the NR/PAni Fibers $_{\text {at room temperature }}$ in the potential range $-0,5 \mathrm{~V}$ to $+0,5 \mathrm{~V}$. The linear dependence of current on voltage indicated an ohmic behavior of NR/ PAni $_{\text {Fibers }}$. Inserted inthe figure above is possible observe the values of resistivity and conductivity calculated by the following equations (1) and (2) respectively: 


$$
\begin{array}{r}
R=\rho \frac{l}{A} \\
\sigma=\frac{1}{\rho}
\end{array}
$$

where is the electrical resistance of membranes $(\Omega), \rho$ represents the electrical resistivity $(\Omega . m)$, is the sample length $(\mathrm{m})$, is referent the cross-section area of the sample $\left(\mathrm{m}^{2}\right)$ and, $\sigma$ represents the electrical conductivity $\left(\mathrm{S} . \mathrm{m}^{-1}\right)$.

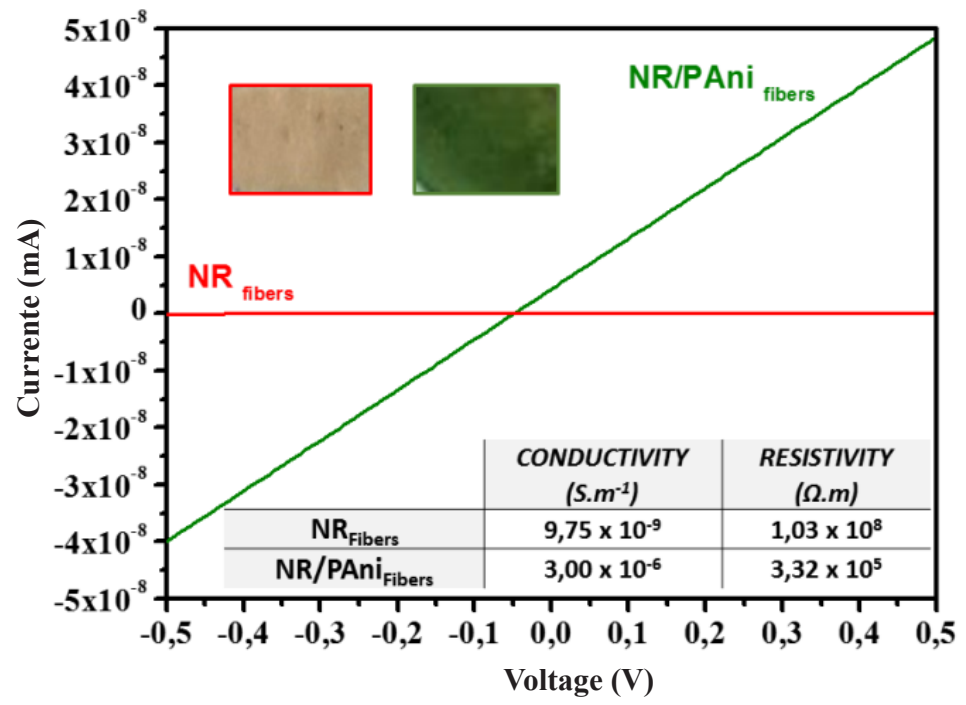

Figure 8: Shows the current-voltage (I-V) characteristics of the natural rubber fibers $\left(\mathrm{NR}_{\mathrm{Fibers}}\right)$ and the natural rubber/ polyaniline fibers $\left(\mathrm{NR} / \mathrm{PAni}_{\text {Fibers }}\right)$. In detail are showing the photography of the electrospun membranes before and after add polyaniline; the table shows the conductivity and resistivity values for both samples.

As expected, the natural rubber fibers show high resistivity around to $1 \times 10^{8} \Omega . \mathrm{m}$ which qualifies the membranes as insulating materials. After PAni deposition the resistivity decrease to $3.32 \times 10^{5} \Omega . \mathrm{m}$ as well as increases the conductivity to $3.0 \times 10^{-6} \mathrm{~S}^{-1}$. It is known that the conductivity of solid materials is caused by the number of carriers and the mobility of these carriers. The conjugated polymers have a large number of carriers, but a low mobility. For this reason, lead in low conductivity orders [40].

In this sense, the materials described in this paper reached values of electrical conductivity in the semiconductor range around to $10^{-6} \mathrm{~S} . \mathrm{m}^{-1}$ for NR/PAni ${ }_{\text {Fibers }}$, and can be applied as melamine (1,3,5-triazine-2,4,6-triamine) sensor [41]; ammonia sensors [42, 43]; radiation sensors [44]; $\mathrm{H}_{2} \mathrm{~S}$ and $\mathrm{SO}_{2}$ sensors [45] and strain sensor [46].

It was observed from the $\mathrm{I}-\mathrm{V}$ curve that the $\mathrm{NR} / \mathrm{PAni}_{\text {Fibers }}$ has ohmic behavior increased the current from $3.90 \times 10^{-8}$ $\mathrm{mA}$ to $4.77 \times 10^{-8} \mathrm{~mA}$ as the voltage increased. It is expected that the PAni molecules be incorporated into the natural rubber fibbers, i.e. into the porous surface due the fibers presence.

\section{CONCLUSIONS}

Oriented fibers and self-standing non-woven mats were prepared from NR by electrospinning, and their morphological, structural and thermcalproperties were characterized. The average diameter of the NR fibers was approximately $5.5 \mu \mathrm{m}$. Self-standing, non-woven mats fabricated using an organic polymer (such as NR) could lead to the production of biocompatible and flexible fibrous materials. Moreover, highly oriented fibers will improve the homogeneity and uniformity of porous mats. Through the study is possible to suggest the application in sensor, as confirmed by the electrical characterization after the polyaniline deposition. 


\section{ACKNOWLEDGEMENTS}

The authors gratefully acknowledge the following Brazilian agencies for financial support in their research activity: FAPESP (Number 2013/18692-6); INCT/INEO/CAPES and ProPg/UNESP for support. We would also like to thank LabMMev for the SEM image.

\section{BIBLIOGRAPHY}

[1] DOSHI, J., RENEKER, D.H. “Electrospinning process and applications of electrospun fibers”, J. Electrostat. n. 35, pp. 151-160, 1995.

[2] BHARDWAJ, N., KUNDU, S.C. "Electrospinning: a fascinating fiber fabrication technique”, Biotechnol. Adv. n. 28, pp. 325-347, 2010.

[3] ZEYTUNCU, B., AKMAN, S., YUCEL, S.O., et al. "Preparation and Characterization of UV-Cured Hybrid Polyvinyl Alcohol Nanofiber Membranes by Electrospinning”, Mater. Res. n. 17, pp. 565-569, 2014.

[4] KHOSHNEVISAN, K., MALEKI, H., et al. "Cellulose acetate electrospun nanofibers for drug delivery systems: Applications and recent advances", Carb. Polymers, n. 198, pp. 131-141, 2018.

[5] HAIDER, A., HAIDER, S., KANG, I.K. “A comprehensive review summarizing the effect of electrospinning parameters and potential applications of nanofibers in biomedical and biotechnology", Arab. J. Chemistry, n. 11, pp. 1165-1188, 2018 .

[6] LIAO, Y., LOH, C.H.; TIAN, M., et al. "Progress in electrospun polymeric nanofibrous membranes for water treatment: Fabrication, modification and applications", Prog. Polymer Sci, n. 77, pp. 69-94, 2018.

[7] NEO, Y.P., RAY, S., PERERA, C.O., "Fabrication of Functional Electrospun Nanostructures for Food Applications" Role of Materials Science in Food Bioengineering, pp. 109-146, 2018.

[8] WANG, Y., HAO, J., HUANG, Z., et al. "Flexible electrically resistive-type strain sensors based on reduced graphene oxide-decorated electrospun polymer fibrous mats for human motion monitoring”, Carbon, n. 126, pp. 360-371, 2018.

[9] HAN, W.H., WANG, Y.Z., SU, J.M., et al. "Fabrication of nanofibrous sensors by electrospinning” Sci. China Technol.. Sci., n. 62, pp. 886-894, 2019.

[10] BIAN, S., JAYARAM, S., CHERNEY, E.A. "Electrospinning as a new method of preparing nanofilled silicone rubber composites”, IEEETrans. Dielect. Elect. Insul., n. 19, pp. 777-785, 2012.

[11] HUANG, C., CHEN, S., LAI, C., et al. "Electrospun polymer nanofibres with small diameters", Nanotechnology, $\mathrm{n}$. 17, pp. 1558-1563, 2006.

[12] SHIN, Y.M., HOHMAN, M.M., BRENNER, M.P., et al."Electrospinning: A whipping fluid jet generates submicron polymer fibers"Appl. Phys. Lett., n. 8, pp. 1149-1151, 2001.

[13] THOMPSON, C.J., CHASE, G.G., YARIN, A.L., et al."Effects of parameters on nanofiber diameter determined from electrospinning model”, Polymer, n. 48, pp. 6913-6922, 2007.

[14] ADEOSUN, S., TAIWO, O., AKPAN, E., et al."Mechanical characteristics of groundnut shell particle reinforced polylactide nano fibre", Revis. Matéria (UFRJ), n. 21, n. 2, pp. 1-10, 2016.

[15] DOERGENS, A., ROETHER, J., DIPPOLD, B., et al. "Identifying key processing parameters for the electrospinning of aligned polymer nanofibers", [Mater. Lett., n. 140, pp. 99-102, 2015.

[16] ABDAL-HAY, A., HAMDY, A.S., KHALIL, K.A. "Fabrication of durable high-performance hybrid nanofiber scaffolds for bone tissue regeneration using a novel, simple in situ deposition approach of polyvinyl alcohol on electrospun nylon 6 nanofibers", Mater. Lett., n. 147, pp. 25-28, 2015.

[17] HU, Q., WU, H., ZHANG, L., et al. "Rubber composite fibers containing silver nanoparticles prepared by electrospinning and in-situ chemical crosslinking”, Express. Polym. Lett., n. 6, pp. 258-265, 2012.

[18] WEN, S., ZHANG, X., YAO, L., et al. "Luminescence studies of electrospun core-sheath fibers with the core component being a rubber nanocomposite containing Eu (III) complex”, J. Mater. Chem. C., n. 1, pp. 1613-1617, 2013.

[19] HSIEH, H.C., CHEN, J.Y.; LEE, W.Y., et al. "Stretchable Fluorescent Polyfluorene/Acrylonitrile Butadiene Rubber Blend Electrospun Fibers through Physical Interaction and Geometrical Confinement", Macromol. Rapid Commun., n. 39 , pp. 1-5, 2017.

[20] KIM, J.R., NETRAVALI, A.N. “One-Step Toughening of Soy Protein Based Green Resin Using Electrospun Epoxidi- 
zed Natural Rubber Fibers”, ACS Sustainable Chem. Eng., n. 5, pp. 4957-4968, 2017.

[21] AGOSTINI, D.L.S., CONSTANTINO, C.J.L., JOB, A.E. "Thermal degradation of both latex and latex cast films forming membranes”,J. Therm. Anal. Calorim., n. 91, pp. 703-707, 2008.

[22] SIMÕES, R.D., JOB, A.E., CHINAGLIA, D.L., et al. "Structural characterization of blends containing both PVDF and natural rubber latex “, J. Raman. Spectrosc., n. 36, pp. 1118-1124, 2005.

[23] JOB, A.E., HERRMANN JR, P.S.P., VAZ, D.O., et al. "Comparison between different conditions of the chemical polymerization of polyaniline on top of PET films”, ऐJ. Appl. Polym. Sci, n. 79, pp. 1220-1229, 2001.

[24] SILVA, M.J., SANCHES, A.O., MALMONGE, L.F.. et al. "Electrical, Mechanical, and Thermal Analysis of Natural Rubber/Polyaniline-DBSA Composite”, Mater. Res. v. 17, pp. 59-63, 2014.

[25] COTTINET, P.J., GUYOMAR, D., GALINEAU, J., et al. "Electro-thermo-elastomers for artificial muscles", Sens. Actuators. A., n. 180, pp. 105-112, 2012.

[26] SCHERILlO, G., LAVORGNA, M., BUONOCORE, G.G., et al. "Tailoring assembly of reduced graphene oxide nanosheets to control gas barrier properties of natural rubber nanocomposites”, ¡ACS. Appl. Mater. Interfaces, n. 6, pp. 2230-2234, 2014.

[27] LIN, T., MA, S., LU, Y., et al. "New design of shape memory polymers based on natural rubber crosslinked via oxa-Michael reaction”, ACS. Appl. Mater. Interfaces, n. 6, pp. 5695-5703, 2014.

[28] QUITMANN, D., GUSHTEROV, N., SADOWSKI, G., et al. "Environmental memory of polymer networks under stress", ¿Adv. Mater, n. 26, pp. 3441-3444, 2014.

[29] QUITMANN, D., GUSHTEROV, N., SADOWSKI, G., et al. "Solvent-sensitive reversible stress-response of shape memory natural rubber”, ACS. Appl. Mater. Interfaces, n. 5, pp. 3504-3507, 2013.

[30] COSTA, L.M.M., MATTOSO, L.H.C., FERREIRA, M. "Electrospinning of PCL/natural rubber blends" 户. Mater. Sci., n. 48, pp. 8501-8508, 2013.

[31] SITHORNKUL, S., THREEPOPNATKUL, P. "Morphology of Electrospun Natural Rubber with Acrylonitrile-Butadiene-Styrene”, Adv. Mat. Res., n. 79, pp. 1583-1586, 2009.

[32] MASCIA, L., SU, R.; CLARKE, J., et al. "Fibres from blends of epoxidized natural rubber and polylactic acid by the electrospinning process: compatibilization and surface texture" Eur. Polym. J., n. 87, pp. 241-254, 2017.

[33] COSME, J.G.L., SILVA, V.M., NUNES, R.R.C., et al. "Development of Biobased Poly(Lactic Acid)/Epoxidized Natural Rubber Blends Processed by Electrospinning: Morphological, Structural and Thermal Properties", Mater. Sci. Appl. n. 7, pp. 210-219, 2015.

[34] STEJSKAL, J., GILBERT, R.G. "Polyaniline. Preparation of a conducting polymer (IUPAC technical report)", IUPAC. Pure. Appl. Chem., n. 74, pp. 857-867, 2002.

[35] MacDIARMID, A.G., CHIANG, J.C., RICHTER, A.F., et al. "Polyaniline: A new concept in conductive polymers”,Synth. Met., n. 18, pp. 285- 290, 1987.

[36] GALIANI, P.D., MALMONGE, J.A., SANTOS, D.P., et al. "Compósitos de borracha natural com polianilina”, Polimeros, n. 17, 93-97, 2007.

[37] KALASAD, M.N., GADYAL, M.A., HIREMATH, R.K., et al. "Synthesis and characterization of polyaniline rubber composites",Compos. Sci. Technol., n. 68, 1787-1793, 2008.

[38] DALL'ANTONIA, A.C., MARTINS, M.A., ORENO, R.M.B., et al. "Avaliação de clones de borracha natural crua por ensaios padrão e análise dinâmico-mecânica”, Polímeros, v. 16, n. 3, pp. 239-245, 2006.

[39] DUARTE, G.W., NASPOLINI, A.M., TACHINSKI, C.G. et al. "Study of the effect of synthesis parameters in the electrical conductivity of the composite poly(vinylidene fluoride)/polyaniline", Revis. Matéria (UFRJ), v. 22, n. 3, pp. $1-11,2017$.

[40] MAIA, D.J., DE PAOLI, M.A., ALVES, O.L., et al. "Síntese de polímeros condutores em matrizes sólidas hospedeiras", Quím. Nova, n. 23, pp. 204-215, 2000.

[41] RAO, H., CHEN, M., GE, H., et al. “A novel electrochemical sensor based on Au@PAni compositesfilm modified glassy carbon electrode binding molecular imprinting technique for the determination of melanine. Biosens. Bioelectron, n. 87, pp. 1029-1035, 2017.

[42] KUMAR, L., RAWAL, I., KAUR, A., et al. "Flexible room temperature ammonia sensor based on polyaniline", Sens. Actuators. B., n. 240, pp. 408-416, 2017. 
[43] WU, Z., CHEN, X., TIAN, X., et al. "Interdigitated transducer ammonia sensors based on nanodiamond/polyaniline thin film”, Electron. Lett., n. 52, pp. 542-544, 2016.

[44] TAMURA, M., MIYATA, H., KATSUMATA, M., et al. "Beta particle detection efficiency of the radiation sensor made from a mixture of polyaniline and titanium oxide", [Nucl. Instr. Meth. Phys. Res. A, n. 828, pp. 176-180, 2016.

[45] DONG, X., ZHANG, X., WU, X., eet al. "Investigation of Gas-Sensing Property of Acid-Deposited Polyaniline Thin-Film Sensors for Detecting $\mathrm{H}_{2} \mathrm{~S}$ and $\mathrm{SO}_{2}$ ”, Sensors, n. 16, pp. 1-15, 2016.

[46] YU, G., YAN, X.;YU, M., et al. "Patterned, highly stretchable and conductive nanofibrous PANI/PVDF strain sensors based on electrospinning and in situ polymerization”, Nanoscale 8, pp. 2944-2950, 2016.

\section{ORCID}

Guilherme Dognani

André Antunes da Silva

Flávio Camargo Cabrera

Fabrício Luiz Faita

Carlos Alberto Tello Saénz

Ivan Helmulth Bechtold

Aldo Eloizo Job

Deuber Lincon da Silva Agostini http://orcid.org/0000-0002-6794-8440

http://orcid.org/0000-0003-0149-2310

http://orcid.org/0000-0001-7924-7089

http://orcid.org/0000-0003-3107-0936

http://orcid.org/0000-0002-0369-8999

http://orcid.org/0000-0001-6393-7245

http://orcid.org/0000-0002-1979-8257

http://orcid.org/0000-0001-9358-2086 